\title{
GENERAL
}

\section{A POLICY VIEW: GAPS AND WEAKNESSES OF SUBSTITUTION BETWEEN BIOLOGICAL PRODUCTS IN LAW AND ECONOMICS DIMENSION: THE EXAMPLE OF INSULIN}

\author{
KATARZYNA ANNA GRUCHAŁA ${ }^{1 *}$, PIOTR WĄŻं ${ }^{3}$ PIOTR KAWCZAK², \\ AGNIESZKA ZIMMERMANN' ${ }^{1}$, BOGUMIŁ WOLNIK ${ }^{4}$ and TOMASZ BĄCZEK ${ }^{2}$
}

${ }^{1}$ Department of Medical and Pharmacy Law, Faculty of Health Sciences with Subfaculty of Nursing and Institute of Maritime and Tropical Medicine, Medical University of Gdansk,

Tuwima 15 Street, 80-210 Gdańsk, Poland

${ }^{2}$ Department of Pharmaceutical Chemistry, Faculty of Pharmacy, Medical University of Gdansk,

Al. Gen. J. Hallera 107, 80-416 Gdańsk, Poland

${ }^{3}$ Department of Nuclear Medicine, Medical University of Gdansk,

Tuwima 15 Street, 80-210 Gdańsk, Poland

${ }^{4}$ Department of Hypertension and Diabetology, Faculty of Medicine, Medical University of Gdansk,

Dębinki 7, 80-211 Gdańsk, Poland

\begin{abstract}
The purpose of the study is to analyze the act of substitution between biological products. Diabetes mellitus notes the greatest increase in the projected causes of deaths globally till 2030 . The proper drug substitution process may help to increase the control over the disease management. In this paper, authors try to identify and explain the challenges for the health policies and legislations in emerging markets and low- and middle-income countries. Analysis of retrospective data covering prescribed-dispensed insulin products was performed. The study is based on the law and economics approach with the application of the planning theory and modeling. The study shows the scope of substitution process of insulin and highlights the necessity of univocal legal approach profiled for this therapy area. Prognosis of created base model indicates at constant presence of substitution process of insulin. Substitution is to bring financial savings for patients, it is yet however unknown whether savings arising from the act of purchase will still have a positive impact on undertaken therapy process in long-term period. These findings may inform about important factors and how emerging markets and lowand middle-income countries can increase progress of the substitution process.
\end{abstract}

Keywords: insulin, biosimilars, Substitution, drug policy, legislation

A biological medicinal product is an outcome of a modification of biological processes and is prepared using, for example, genetically engineered cells or bacteria. According to the World Health Organization (WHO), such products include cytokines, growth factors, hormones, interferons, products from novel cell lines, and other regulatory peptides and proteins (1). Biological products largely play an important role in today's medicine as they have brought new possibilities of treating diseases previously identified as untreatable. The European Medicines Agency (EMA) stresses that their "complexity as well as the way they are produced may result in a degree of variability in molecules of the same active substance, particularly in different batches of the medicine", at the same time highlighting that this variability must not affect the safety of their effectiveness. Products defined as similar biotherapeutics (SBPs) arose from the limited use of innovative biotherapeutic products (BTPs) due to their high price (2). Therefore, increased access to biological medicinal products at an affordable level is a desired result. The EMA, however, does not present potential recommendations on the interchangeable use of SBPs and BTPs, focusing on authorization purposes, and leaving issues of interchangeability to medical doctors and pharmacists (3). SBPs are expected to have structural or func-

* Corresponding author: e-mail: katarzynagruchala@gumed.edu.pl 
tional differences in comparison to reference biological products, and those differences may impact clinical efficacy, safety, purity or pharmacokinetics (4). The Food and Drug Administration (FDA) highlights that: "In contrast to most drugs that are chemically synthesized and their structure is known, most biologics are complex mixtures that are not easily identified or characterized" (5). The WHO supports the regulation of biotherapeutics, aiming at providing a comprehensive framework of support and advice, as increased access to biotherapeutic products has been identified as a "global public health priority" (6). The issue of substitution between BTPs and SBPs may not, therefore, be left without regulatory measures.

Substitution is a process which arises at the pharmacy level without the physicians' knowledge. It exists between reference drugs and those considered to be similar. It is the pharmacist who performs the substitution, sometimes unintentionally intervening in the undertaken therapy field. Pharmacists have their professional ethics; they cannot be pushed by inappropriate, lacking, misleading or neglected regulations to act disrespectfully or remain unprotected. The performance of substitution, sometimes unintentional, may therefore be a critical aspect of the therapy process, as a similar biotherapeutic product is to be intentionally seen as a new independent product. The consensus reached in Europe is not to switch patients to another biologic drug without a medical reason (7). A switch is defined as a decision made by the treating physician, as a part of the medical practice. A substitution and a switch by definition are not seen as the same activity. Furthermore, the definition included in the Canadian document (Biologics Price Competition and Innovation Act of 2009, Section 7002) is noteworthy: "The term interchangeable or interchangeability in reference to a biological product that is shown to meet the standards described in subsection $(k)(4)$, means that the biological product may be substituted for the reference product without the intervention of the healthcare provider who prescribed the reference product" (8). Interchangeability then is not left to the medical doctors or pharmacists, reflecting the authority of the EMA, instead, most European countries undertake this issue on an individual basis.

In this paper, we tackle some of these issues, investigating the gaps and weaknesses they possess and looking closer at some of the reasons for their shortcomings. First, to put the paper in context, we look closer at the safety concerns regarding the substitution of insulin. The drug policy environment in several countries, concerning the substitution of bio- therapeutics, is also discussed, together with the challenges this environment brings to harmonization in the global dimension. Due to the lack of desirable scientific data from low- and middle-income countries (LMICs), the subject issue is extracted from the context of particular countries. Secondly, we investigate the process of the substitution of insulin and its types, taking Poland as a case study. Poland (seen as an emerging market) has no additional guidelines regarding the substitution process, therefore, it is an excellent example of what possible effects the lack of guidelines may bring to both public health and the institutional harmony of a country. The only legal domestic conditions of substitution concern the rINN (recommended International Nonproprietary Name), which must be the same between the substituted products; the dose, which must stay the same; and the pharmaceutical form, which may be changed but still must not cause therapeutic differences (9). The legal conditions of substitution are neither specifically profiled for biological or chemical products, nor utility in key therapy areas. Most LMICs suffer the absence of substitution policies (like Poland); therefore, considerations made within this paper may bring some practical knowledge of the process and suggest further actions in the implementation of effective substitution regulations and their enforcement through legislation among a wider scope of countries. Subsequently, we move on to discuss the legal and economic dimension in general, together with the process of planning concerning the subject. We investigate the effects of the law in force on the practical dimension of the substitution process of biologics with the effects it produces on the social and institutional background of the health care system.

Diabetes mellitus, by 2030 , is projected to reach $7^{\text {th }}$ place in the ranking of the 15 leading causes of death (10). Out of 15 diseases, 8 moved up in the ranking, 5 down (including malaria, tuberculosis, and diarrhoeal diseases) and 2 remained the same (ischaemic heart disease, cerebrovascular disease). In 2002, diabetes mellitus ranked $11^{\text {th }}$, thus the move of 4 places up in the ranking was notified as the second greatest change in the projected period in the ranking (after stomach cancer). The increase in importance is accordingly noticeable. According to the WHO, currently 1 in 11 people suffer from diabetes mellitus, which is present in all countries regardless of income (11). In 2030, it is projected to still be among the 10 most common causes of death in all countries, regardless of income.

Substitution policies continue to be widely quoted, especially in terms of authorization levels, 
although they are still substantially mysterious, particularly in terms of the differences in the practical setting of various conditions. To address the widespread demand for profiled information on future trends and decision-making, we have prepared base projections.

\section{MATERIALS AND METHODS}

Safety concerns regarding the substitution of insulin and the biologics INN dilemma have been distinguished. The substitution arises at the pharmacy level, therefore, from the practical and thus the policy point of view, it is vital to be able to quickly and correctly identify an SBP. An INN, as the WHO defines, is "specific to a given defined substance, regardless of the manufacturer and manufacturing site, even though the profile of impurities may not be qualitatively or quantitatively the same". The complex nature of biological medicines, however, may well lead to differences in final clinical efficacy and safety profiles (4). The WHO has already undertaken the creation of guidelines aiming at avoiding the production of different national naming regulations. A "Biological qualifier" is to provide clear identification of individual biological products recognizable at the worldwide level (12). From the substitution policy point of view, and aspects considered in the study of this paper, such full harmonization of the naming convention in the global dimension is extremely desirable, as its presence may positively influence both dispensing and prescribing, and eliminate confusion among pharmacists and treating physicians, but also confusion at the regulatory level (13).

The presence of reverse- or cross-substitution in the policy view must also be considered, as it is theoretically possible to undergo a substitution not only between BTP and SBP, but also SBP and BTP, and between SBPs.

A switch of insulin has been scientifically researched with regard to safety measures. However, many important issues with regard to the subject of this paper still remain unsolved. Studies show that in clinical practice, physicians see the necessity of patient control in changing the medication (14-16). And furthermore, the urgency to educate patients about the contrasting timing of the injections and the type of injector (17-20). A glycemic target, which is recommended from the top, is intended to prevent complications in the long-term period and avoid frequent hypoglycemic episodes (21). A switch of insulin, thus, should be preceded by the observation of a patient by the treating physician (22), especial- ly between types of insulin which require more clinical commitment (23). Substitution at the pharmacy level is widely lacking this observation in regard to policy and legal circumstances.

Some European countries prohibit the substitution of biosimilars (23). Some have even enacted certain laws to directly forbid this process. Other European countries accept substitution, as new studies arise, between biologics, under certain conditions, i.e. "adequate clinical monitoring" and "proper information for the patient" $(24,25)$. However, these conditions may also suggest the performance of the switch, not strictly the origin of the substitution arising at the pharmacy level without the knowledge of the treating physician. The Netherlands recommends "detailed product and batch information to be recorded in the patient file in order to guarantee traceability of the product" $(24,26)$, which seems to be helpful for the typical substitution process. A unique, unequivocal legal approach to the subject is, however, lacking. It is yet unknown, although extremely interesting, how this issue is tackled by other countries, especially those of middle- and low-income, and what eventual effects the legal conditions bring to the practical conditions in regard to the legal and economic dimension. Discussion over the clarification and differentiation of definitions on a legal basis seems to be more than reasonable for the global harmony of the process, as most countries experience both the issue of diabetes mellitus and of substitution.

Since 2012, Polish-based pharmacies are legally (Reimbursement Act of 2012) obliged to report every 14 days to the National Health Fund (NFZ), data concerning dispensed reimbursed medicines. And they are also obliged to report whether a medicine was substituted. A retrospective study, based on data received from Poland's National Health Fund, was performed. The obtained data, covering the years 2012-2015, contained a list of medicines substituted as prescribed-dispensed in the form of the EAN (European Article Number) identification number of each medicine. The data contained only medicines with different prescribed-dispensed EANs. Furthermore, the patients' ages or information from which it was possible to calculate the patients' ages were included in the data. The data did not, however, contain the names of active substances. In Poland, a list of all market-authorized medicines in each year is publicly available at the Office for the Registration of Medicinal Products, Medical Devices and Biocidal Products. Due to certain technical issues of identifying each EAN, also publicly available reimbursement lists of medicines 
a)

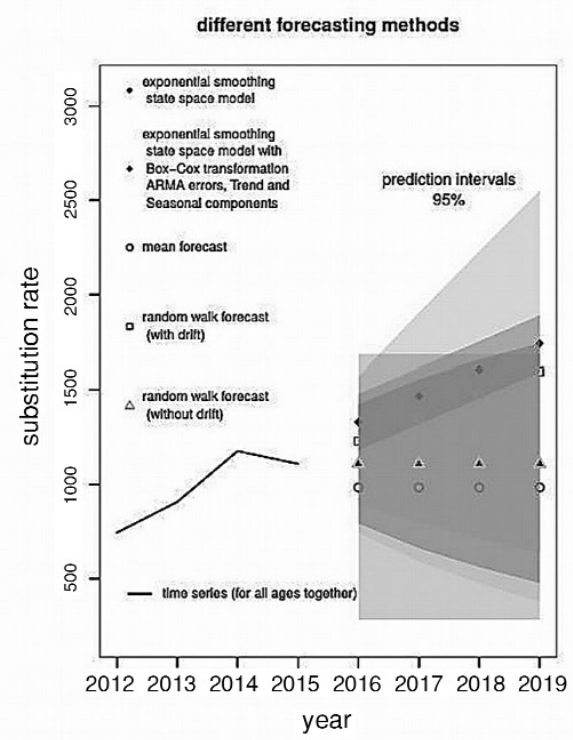

b)

c)

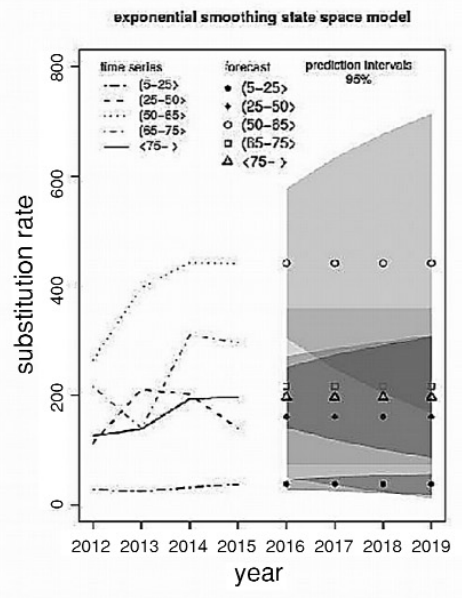

d)

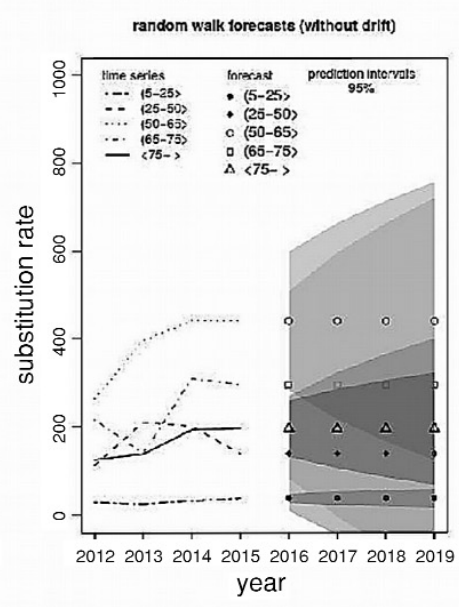

e)

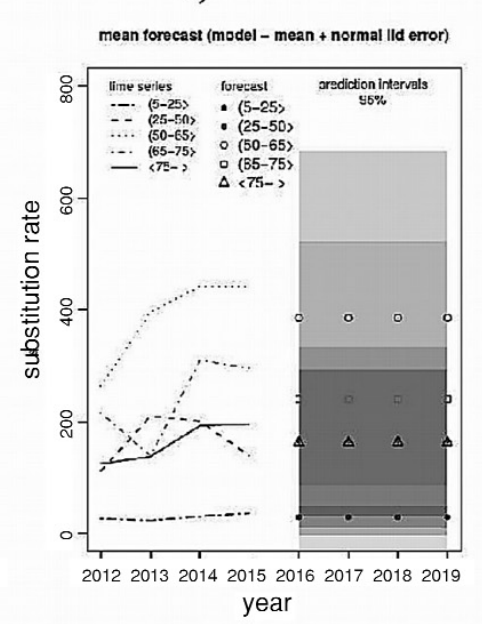

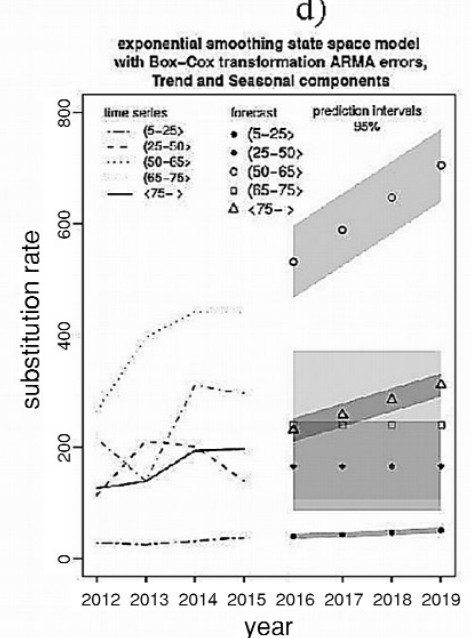

Figure 1. Prognosis of base model 
were used, as a double-check of each EAN-to-active substance match. Because there were differences in naming (English-Latin) among the lists of the Office for the Registration Medicinal Products, Medical Devices and Biocidal Products and the reimbursement lists from the Ministry of Health, which, in contrast, is extremely important in terms of computer programming, a template of the English names and Latin names of active substances has been created. The template contains all active substances arranged due to the ATC classification, specifically the anatomic and therapeutic group, where the EANs were swapped for active substances (compounds).

From the data concerning the substitution process in a 4-year period, those data concerning five regional areas (provinces) were included in the study: Malopolska, West Pomerania, Podlasie, Mazovia, and Silesia. The substitution of insulin was selected as a base model. The base model of insulin was arranged due to the WHO list of recommended insulins' INNs as new types of this medicine were identified within the development of science (27). Table 1 presents the rINN arrangement template of a base model. The only exception made, was the differentiation of human insulin as human regular and human isophane (NPH).

The base model $(\mathrm{n}=3937)$ contains the substitution rate of insulin due to a patient's age in each year. The base model was divided into three groups of results according to the following division: shortacting insulin, long-acting insulin, and biphasic insulin. The first group of results contains the substitution rate of the same type of product but a different manufacturer. The second group of results contains the substitution rate of the same type of product of the same manufacturer but a different pen. Finally, the third group of results contains the substitution rate of different types of insulin products (for example, short-acting substituted for longacting or the substitution between different combinations of biphasic insulin products). The base model was used to predict the substitution rate of insulin in the next 4 years.

Calculations and predictions were performed with the R: A Language and Environment for Statistical Computing, Vienna, Austria (28), and additionally, the figures of groups of results were performed with the use of Statistica v12, Tulsa, USA.

Table 1. The rINNs of insulin.

\begin{tabular}{|c|c|c|}
\hline Year & INN English & INN Latin \\
\hline 1959 & protamine zinc insulin injection & injectio insulini zinci protaminati \\
\hline 1966 & neutral injection of insulin & insulini injectio neutralis \\
\hline 1967 & biphasic insulin injection & insulini injectio biphasica \\
\hline 1983 & insulin human & insulinum humanum \\
\hline 1995 & insulin lispro & insulinum lisprum \\
\hline 1997 & insulin glargine & insulinum glarginum \\
\hline 2001 & insulin glulisine & insulinum glulisinum \\
\hline
\end{tabular}

Table 2. Base model.

\begin{tabular}{|c|c|c|c|c|c|}
\hline Year & 2012 & 2013 & 2014 & 2015 & Total \\
\hline \multicolumn{6}{|c|}{ Age group } \\
\hline $0-5$ & 0 & 0 & 0 & 0 & 0 \\
\hline$\leq 25$ & 27 & 24 & 31 & 37 & 119 \\
\hline$\leq 50$ & 112.5 & 210 & 201 & 139 & 662.5 \\
\hline$\leq 65$ & 264 & 396 & 442 & 441 & 1543 \\
\hline$\leq 75$ & 215.5 & 139 & 310 & 296 & 960.5 \\
\hline $75+$ & 125 & 138 & 193 & 196 & 652 \\
\hline Total & 744 & 907 & 1177 & 1109 & 3937 \\
\hline
\end{tabular}


Table 3. Substitution rate of group of results a.

\begin{tabular}{|c|c|c|c|c|}
\hline Year & 2012 & 2013 & 2014 & 2015 \\
\hline \multicolumn{5}{|c|}{ Short-acting insulin } \\
\hline \multicolumn{5}{|c|}{ Regular insulin (neutral, soluble) } \\
\hline C1. Actrapid ${ }^{\circledR}$ Penfill ${ }^{\circledR} \rightarrow$ Gensulin ${ }^{\circledR} \mathrm{R}$ & 49 & 99 & 147 & 76 \\
\hline C2. Gensulin ${ }^{\circledR} \mathrm{R} \rightarrow$ Actrapid ${ }^{\circledR}$ Penfill ${ }^{\circledR}$ & 13 & 22 & 72 & 22 \\
\hline C3. Gensulin ${ }^{\circledR} \mathrm{R} \rightarrow$ Humulin ${ }^{\circledR} \mathrm{R}$ & 23 & 21 & 4 & 1 \\
\hline C4. Humulin ${ }^{\circledR} \mathrm{R} \rightarrow$ Gensulin ${ }^{\circledR} \mathrm{R}$ & 26 & 20 & 17 & 6 \\
\hline C5. Humulin ${ }^{\circledR} \mathrm{R} \rightarrow$ Actrapid ${ }^{\circledR}$ Penfill ${ }^{\circledR}$ & 22 & 6 & 1 & 0 \\
\hline C6. Actrapid ${ }^{\circledR}$ Penfill ${ }^{\circledR} \rightarrow$ Humulin ${ }^{\circledR} \mathrm{R}$ & 4 & 1 & 1 & 1 \\
\hline C7. Gensulin ${ }^{\circledR} \mathrm{R} \rightarrow$ Polhumin ${ }^{\circledR} \mathrm{R}$ & 3 & 3 & 4 & 1 \\
\hline C8. Polhumin ${ }^{\circledR} \mathrm{R} \rightarrow$ Gensulin ${ }^{\circledR} \mathrm{R}$ & 0 & 0 & 0 & 2 \\
\hline C9. Actrapid ${ }^{\circledR}$ Penfill ${ }^{\circledR} \rightarrow$ Polhumin ${ }^{\circledR} \mathrm{R}$ & 1 & 0 & 0 & 2 \\
\hline C10. Humulin ${ }^{\circledR} \mathrm{R} \rightarrow$ Polhumin ${ }^{\circledR} \mathrm{R}$ & 9 & 1 & 5 & 7 \\
\hline C11. Polhumin ${ }^{\circledR} \mathrm{R} \rightarrow$ Humulin ${ }^{\circledR} \mathrm{R}$ & 2 & 1 & 3 & 6 \\
\hline C12. Gensulin ${ }^{\circledR} \mathrm{R} \rightarrow$ Insuman ${ }^{\circledR}$ Rapid & 1 & 0 & 6 & 0 \\
\hline C13. Polhumin ${ }^{\circledR} \mathrm{R} \rightarrow$ Insuman ${ }^{\circledR}$ Rapid & 0 & 1 & 0 & 0 \\
\hline C14. Insuman ${ }^{\circledR}$ Rapid $\rightarrow$ Gensulin ${ }^{\circledR} \mathrm{R}$ & 1 & 1 & 1 & 0 \\
\hline C15. Insuman ${ }^{\circledR}$ Rapid $\rightarrow$ Actrapid ${ }^{\circledR}$ Penfill ${ }^{\circledR}$ & 0 & 8 & 16 & 18 \\
\hline C16. Actrapid ${ }^{\circledR}$ Penfill ${ }^{\circledR} \rightarrow$ Insuman ${ }^{\circledR}$ Rapid & 0 & 1 & 0 & 0 \\
\hline C17. Insuman ${ }^{\circledR}$ Rapid $\rightarrow$ Humulin ${ }^{\circledR} \mathrm{R}$ & 0 & 0 & 0 & 1 \\
\hline C18. Humulin ${ }^{\circledR} \mathrm{R} \rightarrow$ Insuman ${ }^{\circledR}$ Rapid & 0 & 0 & 0 & 1 \\
\hline \multicolumn{5}{|c|}{ Long-acting insulin } \\
\hline \multicolumn{5}{|c|}{ NPH insulin (isophane) } \\
\hline C19. Polhumin ${ }^{\circledR} \mathrm{N} \rightarrow$ Humulin ${ }^{\circledR} \mathrm{N}$ & 1 & 9 & 4 & 4 \\
\hline C20. Polhumin ${ }^{\circledR} \mathrm{N} \rightarrow$ Gensulin ${ }^{\circledR} \mathrm{N}$ & 11 & 5 & 1 & 2 \\
\hline C21. Polhumin ${ }^{\circledR} \mathrm{N} \rightarrow$ Insultard ${ }^{\circledR}$ Penfill ${ }^{\circledR}$ & 5 & 0 & 0 & 1 \\
\hline C22. Humulin ${ }^{\circledR} \mathrm{N} \rightarrow$ Polhumin ${ }^{\circledR} \mathrm{N}$ & 10 & 4 & 7 & 6 \\
\hline C23. Humulin ${ }^{\circledR} \mathrm{N} \rightarrow$ Gensulin ${ }^{\circledR} \mathrm{N}$ & 28 & 20 & 27 & 21 \\
\hline C24. Humulin ${ }^{\circledR} \mathrm{N} \rightarrow$ Insultard ${ }^{\circledR}$ Penfill ${ }^{\circledR}$ & 3 & 0 & 7 & 8 \\
\hline C25. Gensulin ${ }^{\circledR} \mathrm{N} \rightarrow$ Polhumin ${ }^{\circledR} \mathrm{N}$ & 5 & 4 & 3 & 1 \\
\hline C26. Gensulin ${ }^{\circledR} \mathrm{N} \rightarrow$ Humulin ${ }^{\circledR} \mathrm{N}$ & 6 & 18 & 20 & 13 \\
\hline C27. Gensulin ${ }^{\circledR} \mathrm{N} \rightarrow$ Insultard ${ }^{\circledR}$ Penfill ${ }^{\circledR}$ & 33 & 41 & 31 & 17 \\
\hline C28. Insuman ${ }^{\circledR}$ Basal $\rightarrow$ Insultard ${ }^{\circledR}$ Penfill ${ }^{\circledR}$ & 0 & 9 & 23 & 8 \\
\hline C29. Insultard ${ }^{\circledR}$ Penfill ${ }^{\circledR} \rightarrow$ Polhumin ${ }^{\circledR} \mathrm{N}$ & 11 & 11 & 4 & 1 \\
\hline C30. Insultard ${ }^{\circledR}$ Penfill ${ }^{\circledR} \rightarrow$ Humulin ${ }^{\circledR} \mathrm{N}$ & 2 & 2 & 3 & 2 \\
\hline C31. Insultard ${ }^{\circledR}$ Penfill ${ }^{\circledR} \rightarrow$ Gensulin ${ }^{\circledR} \mathrm{N}$ & 20 & 17 & 9 & 4 \\
\hline C32. Insultard ${ }^{\circledR}$ Penfill ${ }^{\circledR} \rightarrow$ Insuman ${ }^{\circledR}$ Basal & 0 & 0 & 2 & 1 \\
\hline \multicolumn{5}{|c|}{ Long-acting analog insulin (glargine) } \\
\hline C33. Lantus ${ }^{\circledR} \rightarrow$ Abasalgar ${ }^{\circledR}$ & 0 & 0 & 0 & 6 \\
\hline \multicolumn{5}{|c|}{ Biphasic insulin } \\
\hline \multicolumn{5}{|c|}{ Regular + NPH insulin } \\
\hline C34. Polhumin ${ }^{\circledR}$ Mix $3 \rightarrow$ Mixtard ${ }^{\circledR} 30$ Penfill ${ }^{\circledR}$ & 2 & 16 & 0 & 1 \\
\hline C35. Polhumin ${ }^{\circledR}$ Mix $3 \rightarrow$ Gensulin ${ }^{\circledR}$ M30 & 4 & 0 & 1 & 3 \\
\hline C36. Polhumin ${ }^{\circledR}$ Mix $3 \rightarrow$ Humulin ${ }^{\circledR}$ M3 & 0 & 3 & 2 & 0 \\
\hline C37. Humulin ${ }^{\circledR}$ M3 $\rightarrow$ Gensulin ${ }^{\circledR}$ M30 & 13 & 13 & 21 & 17 \\
\hline
\end{tabular}


Table 3. Continued.

\begin{tabular}{|c|c|c|c|c|}
\hline Year & 2012 & 2013 & 2014 & 2015 \\
\hline C38. Humulin ${ }^{\circledR}$ M3 $\rightarrow$ Mixtard ${ }^{\circledR} 30$ Penfill ${ }^{\circledR}$ & 4 & 0 & 1 & 0 \\
\hline C39. Humulin ${ }^{\circledR}$ M3 $\rightarrow$ Polhumin ${ }^{\circledR}$ Mix 3 & 3 & 1 & 0 & 0 \\
\hline C40. Mixtard ${ }^{\circledR} 30$ Penfill ${ }^{\circledR} \rightarrow$ Gensulin ${ }^{\circledR}$ M30 & 25 & 11 & 10 & 5 \\
\hline C41. Mixtard ${ }^{\circledR} 50$ Penfill ${ }^{\circledR} \rightarrow$ Gensulin ${ }^{\circledR}$ M50 & 2 & 6 & 3 & 0 \\
\hline C42. Mixtard ${ }^{\circledR} 30$ Penfill ${ }^{\circledR} \rightarrow$ Polhumin ${ }^{\circledR}$ Mix 3 & 4 & 2 & 0 & 3 \\
\hline C43. Mixtard ${ }^{\circledR} 40$ Penfill ${ }^{\circledR} \rightarrow$ Gensulin ${ }^{\circledR}$ M40 & 5 & 2 & 4 & 0 \\
\hline C44. Mixtard ${ }^{\circledR} 40$ Penfill ${ }^{\circledR} \rightarrow$ Polhumin ${ }^{\circledR}$ Mix 4 & 1 & 0 & 0 & 0 \\
\hline C45. Mixtard ${ }^{\circledR} 50$ Penfill ${ }^{\circledR} \rightarrow$ Polhumin $^{\circledR}$ Mix 5 & 1 & 0 & 0 & 0 \\
\hline C46. Mixtard ${ }^{\circledR} 30$ Penfill ${ }^{\circledR} \rightarrow$ Humulin ${ }^{\circledR}$ M3 & 2 & 0 & 0 & 0 \\
\hline C47. Gensulin ${ }^{\circledR}$ M30 $\rightarrow$ Mixtard ${ }^{\circledR} 30$ Penfill ${ }^{\circledR}$ & 26 & 28 & 14 & 31 \\
\hline C48. Gensulin ${ }^{\circledR}$ M30 $\rightarrow$ Humulin ${ }^{\circledR}$ M3 & 12 & 8 & 3 & 14 \\
\hline C49. Polhumin ${ }^{\circledR}$ Mix $5 \rightarrow$ Mixtard ${ }^{\circledR} 50$ Penfill ${ }^{\circledR}$ & 0 & 6 & 0 & 3 \\
\hline C50. Gensulin ${ }^{\circledR}$ M30 $\rightarrow$ Polhumin ${ }^{\circledR}$ Mix 3 & 10 & 3 & 0 & 0 \\
\hline C51. Polhumin ${ }^{\circledR}$ Mix $5 \rightarrow$ Gensulin ${ }^{\circledR}$ M50 & 1 & 1 & 0 & 2 \\
\hline C52. Gensulin ${ }^{\circledR}$ M50 $\rightarrow$ Mixtard ${ }^{\circledR} 50$ Penfill ${ }^{\circledR}$ & 3 & 25 & 1 & 13 \\
\hline C53. Polhumin ${ }^{\circledR}$ Mix $4 \rightarrow$ Gensulin ${ }^{\circledR}$ M40 & 1 & 0 & 0 & 0 \\
\hline C54. Gensulin ${ }^{\circledR}$ M40 $\rightarrow$ Mixtard ${ }^{\circledR} 40$ Penfill ${ }^{\circledR}$ & 4 & 0 & 15 & 1 \\
\hline C55. Gensulin ${ }^{\circledR}$ M40 $\rightarrow$ Polhumin ${ }^{\circledR}$ Mix 4 & 1 & 0 & 0 & 1 \\
\hline C56. Polhumin ${ }^{\circledR}$ Mix $4 \rightarrow$ Mixtard ${ }^{\circledR} 40$ Penfill ${ }^{\circledR}$ & 1 & 0 & 0 & 0 \\
\hline Total & 414 & 354 & 363 & 267 \\
\hline
\end{tabular}

\section{RESULTS}

The results introduce the substitution rates of insulin. The base model is presented in Table 2 . Predictions of the base model are presented in Figure 1. Further groups of results are presented in Tables 3-5 and in Figure 2, Figures 3 and 4 present exemplary scatter plots of the loadings obtained with the use of data from Tables 3 and 4 obtained by PCA.

\section{DISCUSSION}

The base model prognosis indicates a constant presence of the substitution process of insulin. Different forecasting methods show that insulin will undergo the substitution process in the future. The question of whether it will in fact rise or stay at a constant level is, however, dependent on various conditions, especially market and reimbursement conditions. Figure 1 shows different types of prognosis of the base model. ETS (Exponential Smoothing or Error Trend Season) - a universal family of time series models proposed by Hyndman and others (2002) (generalization of exponential smoothing methods). The ETS model consists of a differential equation describing the evolution, and assumptions about the distribution of the random factor. Trigonometric BATS (Box-Cox transform, ARMA errors, Trend, Seasonal) componentsadvanced decomposition and forecasting techniques, developed for a series with complex (multiseasonal) seasonality. The algorithm allows for additional data properties such as the presence of long-term trends or heterogeneous time variances. In the mean forecast method, the value of the predicted variable is replaced by its arithmetic mean. For a small amount of data, the method smooths out the series more smoothly but slows down responses to changes in the level of the predicted variable. For a small amount of data, the method responds more quickly to changes occurring in the values of the predicted variable, but it is more influenced by random fluctuations (less smoothing effect). The mean model is also the starting point for constructing forecasting models for time series data, including random walk and ARIMA models. They differ in that exponential smoothing takes into account all 
Table 4. Substitution rate of group of results b.

\begin{tabular}{|c|c|c|c|c|}
\hline Year & 2012 & 2013 & 2014 & 2015 \\
\hline \multicolumn{5}{|c|}{ Short-acting insulin } \\
\hline \multicolumn{5}{|c|}{ Analog (lispro, glulisine) } \\
\hline D1. Humalog ${ }^{\circledR}$ KwikPen $\rightarrow$ Humalog ${ }^{\circledR} 0$ & 58 & 0 & 0 & 0 \\
\hline D2. Humalog ${ }^{\circledR} 0 \rightarrow$ Humalog ${ }^{\circledR}$ KwikPen & 51 & 0 & 0 & 0 \\
\hline D3. Insuman ${ }^{\circledR}$ Rapid $\rightarrow$ Insuman ${ }^{\circledR}$ Rapid SoloStar & 1 & 8 & 19 & 43 \\
\hline D4. Insuman ${ }^{\circledR}$ Rapid SoloStar $\rightarrow$ Insuman ${ }^{\circledR}$ Rapid & 0 & 4 & 14 & 42 \\
\hline D5. Apidra ${ }^{\circledR}$ SoloStar $\rightarrow$ Apidra ${ }^{\circledR}$ OptiPen & 2 & 13 & 35 & 13 \\
\hline D6. Apidra ${ }^{\circledR}$ OptiPen $\rightarrow$ Apidra ${ }^{\circledR}$ SoloStar & 3 & 13 & 42 & 49 \\
\hline \multicolumn{5}{|c|}{ Long-acting insulin } \\
\hline \multicolumn{5}{|c|}{ NPH insulin (isophane) } \\
\hline D7. Insuman ${ }^{\circledR}$ Basal $\rightarrow$ Insuman ${ }^{\circledR}$ Basal SoloStar & 11 & 45 & 103 & 111 \\
\hline D8. Insuman ${ }^{\circledR}$ Basal SoloStar $\rightarrow$ Insuman ${ }^{\circledR}$ Basal & 14 & 75 & 153 & 169 \\
\hline \multicolumn{5}{|c|}{ Analog (glargine) } \\
\hline D9. Lantus ${ }^{\circledR}$ OptiPen $\rightarrow$ Lantus ${ }^{\circledR}$ SoloStar & 49.5 & 69 & 53 & 63 \\
\hline D10. Lantus ${ }^{\circledR}$ SoloStar $\rightarrow$ Lantus ${ }^{\circledR}$ OptiPen & 71 & 183 & 160 & 102 \\
\hline \multicolumn{5}{|c|}{ Biphasic insulin } \\
\hline \multicolumn{5}{|c|}{ Regular + NPH insulin } \\
\hline D11. Insuman ${ }^{\circledR}$ Comb25 SoloStar $\rightarrow$ Insuman ${ }^{\circledR}$ Comb25 & 1 & 69 & 111 & 140 \\
\hline D12. Insuman ${ }^{\circledR}$ Comb25 $\rightarrow$ Insuman ${ }^{\circledR}$ Comb25 SoloStar & 6 & 57 & 106 & 103 \\
\hline \multicolumn{5}{|c|}{ Lispro + Lispro protamin } \\
\hline D13. Humalog ${ }^{\circledR}$ Mix25 KwikPen $\rightarrow$ Humalog ${ }^{\circledR}$ Mix25 & 12 & 0 & 0 & 0 \\
\hline D14. Humalog ${ }^{\circledR}$ Mix 25 $\rightarrow$ Humalog ${ }^{\circledR}$ Mix 25 KwikPen & 20.5 & 0 & 0 & 0 \\
\hline D15. Humalog ${ }^{\circledR}$ Mix50 KwikPen $\rightarrow$ Humalog ${ }^{\circledR}$ Mix50 & 12 & 0 & 0 & 0 \\
\hline D16. Humalog ${ }^{\circledR}$ Mix50 $\rightarrow$ Humalog ${ }^{\circledR}$ Mix50 KwikPen & 14 & 0 & 0 & 0 \\
\hline Total & 326 & 536 & 796 & 835 \\
\hline
\end{tabular}

Table 5. Substitution rate of group of results c.

\begin{tabular}{|c|c|c|c|c|}
\hline Year & 2012 & 2013 & 2014 & 2015 \\
\hline \multicolumn{5}{|c|}{ Short-acting insulin } \\
\hline Regular insulin (neutral, soluble) & 0 & 2 & 1 & 5 \\
\hline \multicolumn{5}{|c|}{ Long-acting insulin } \\
\hline NPH insulin (isophane) & 0 & 0 & 1 & 1 \\
\hline \multicolumn{7}{|c|}{ Biphasic insulin } & 11 & 5 \\
\hline Regular + NPH insulin & 10 & 9 & 0 & 1 \\
\hline Lispro + Lispro protamin & 0 & 0 & 13 & 12 \\
\hline Total & 10 & 11 & 13 & 5 \\
\hline
\end{tabular}

past data, whereas the moving average only takes into account past data points. Finally, the randomwalk-without-drift model assumes that at each point in time, the series merely takes a random step away from its last recorded position, with steps whose mean value is zero. If the mean step size is a nonzero value $\alpha$, the process is said to be a random-walkwith-drift.

In Figure 1, prediction a) focuses on insulin regardless of the age group of a patient. It presents 


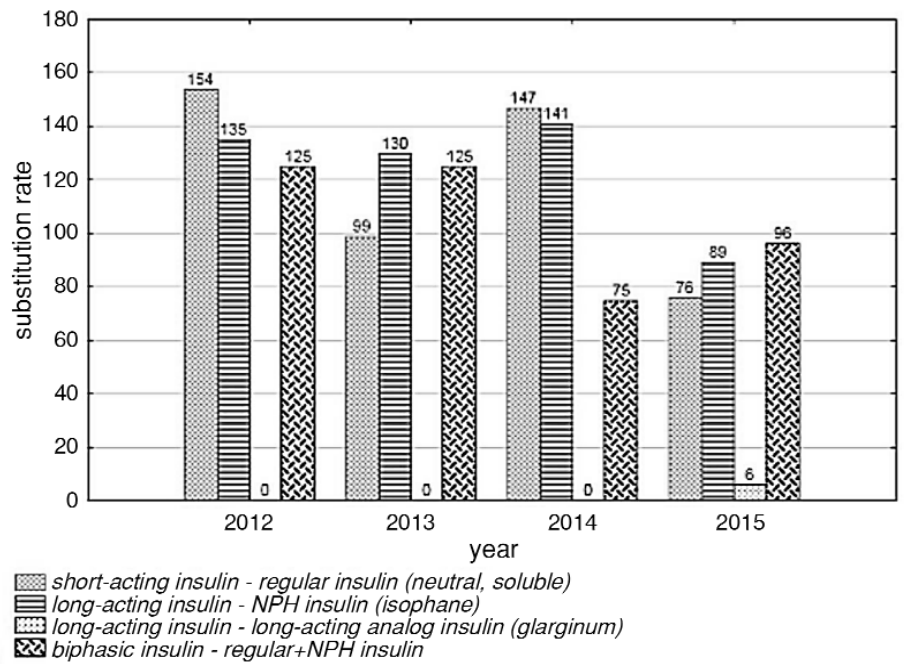

a)
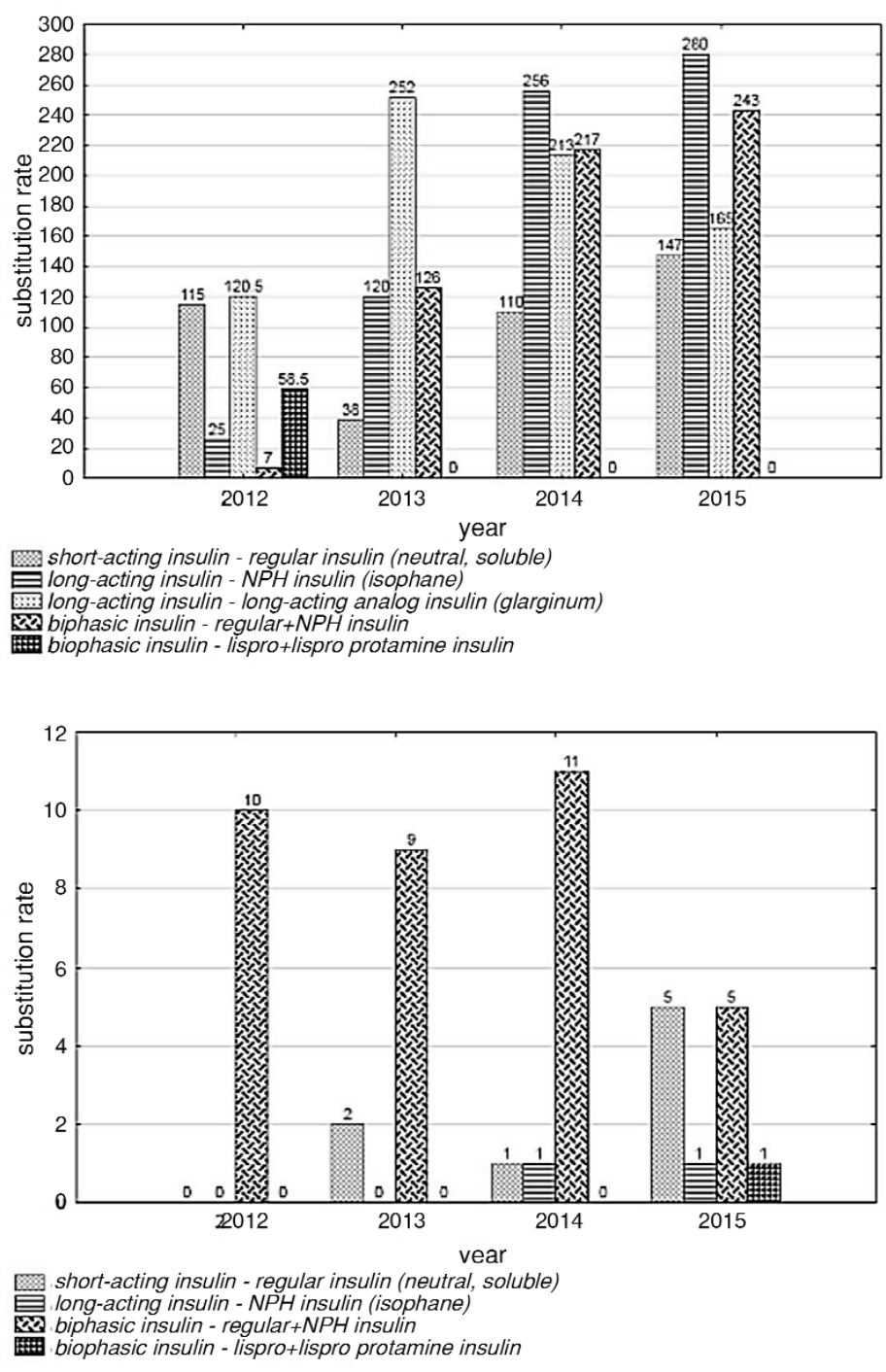

Figure 2. Substitution rates of groups of results 
possible behaviors of the substitution process for the next four years. Each colored area indicates the possible range of behavior of the substitution rate for each model. The symbols represent the mean values for each colored area. Predictions b), c), d) and e) of Figure 1 show the possible behavior of the substitution rate of insulin for set age groups of patients. Like prediction a), each colored area indicates the possible range of behavior of the substitution rate for each age group, whereas the symbols represent the mean values for each colored area. A priori substitution is intended to bring financial savings for patients; however, it is yet unknown whether savings arising from the act of purchase will still have a positive impact on the undertaken therapy process in the long-term period. Even if savings are gained at the moment of purchase, will the process cause higher spending afterward if the substitution, due to a neglected regulation, occurred where it should not? Therefore, a question arises about whether the circumstances of an unplanned and uncontrolled process may result not in savings, but in higher money consumption when considering the broader objective. It is noticeable that different age groups of patients undergo this process, from pediatric to geriatric. Substitution between different products of short-acting insulin, long-acting insulin and its analogs, and biphasic insulin is present at the pharmacy level. Substitution dependent on the type of pen between short-acting insulin, long-acting insulin and its analogs, and biphasic insulin and its analogs is also present at the pharmacy level. The study shows that substitution dependent on the type of pen rapidly increased from 2012 to 2015, whereas substitution between different manufactures noted a slight decrease.

The study also identified substitution errors, understood as changes made between types of insulin. The above-mentioned are presented in Figure 2, in which a) represents the sub-model according to the manufacturer, b) according to the

Substitution rate of group of results a

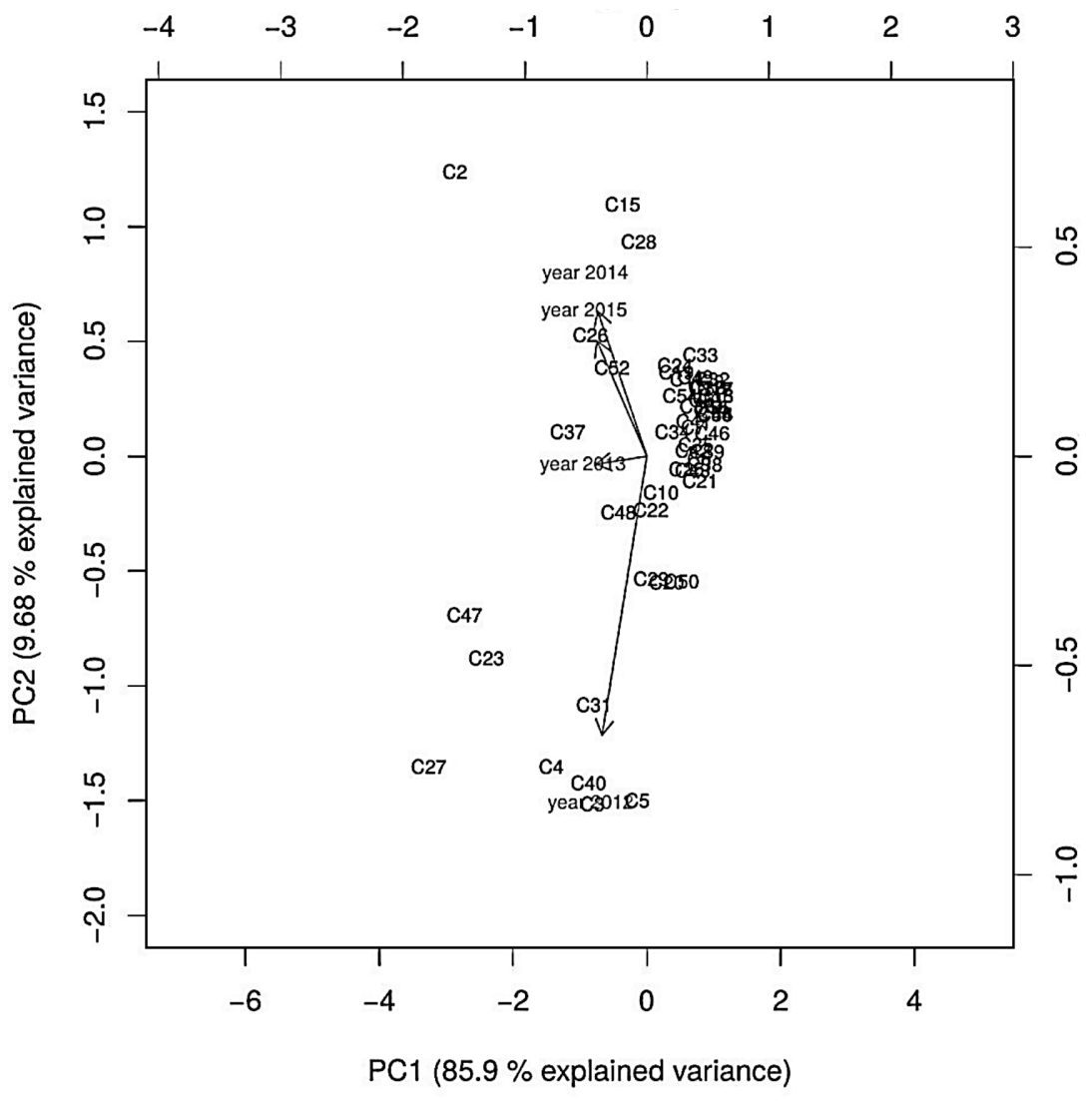

Figure 3. Exemplary scatter plots of the loadings obtained with the use of data from Table 3 by PCA 


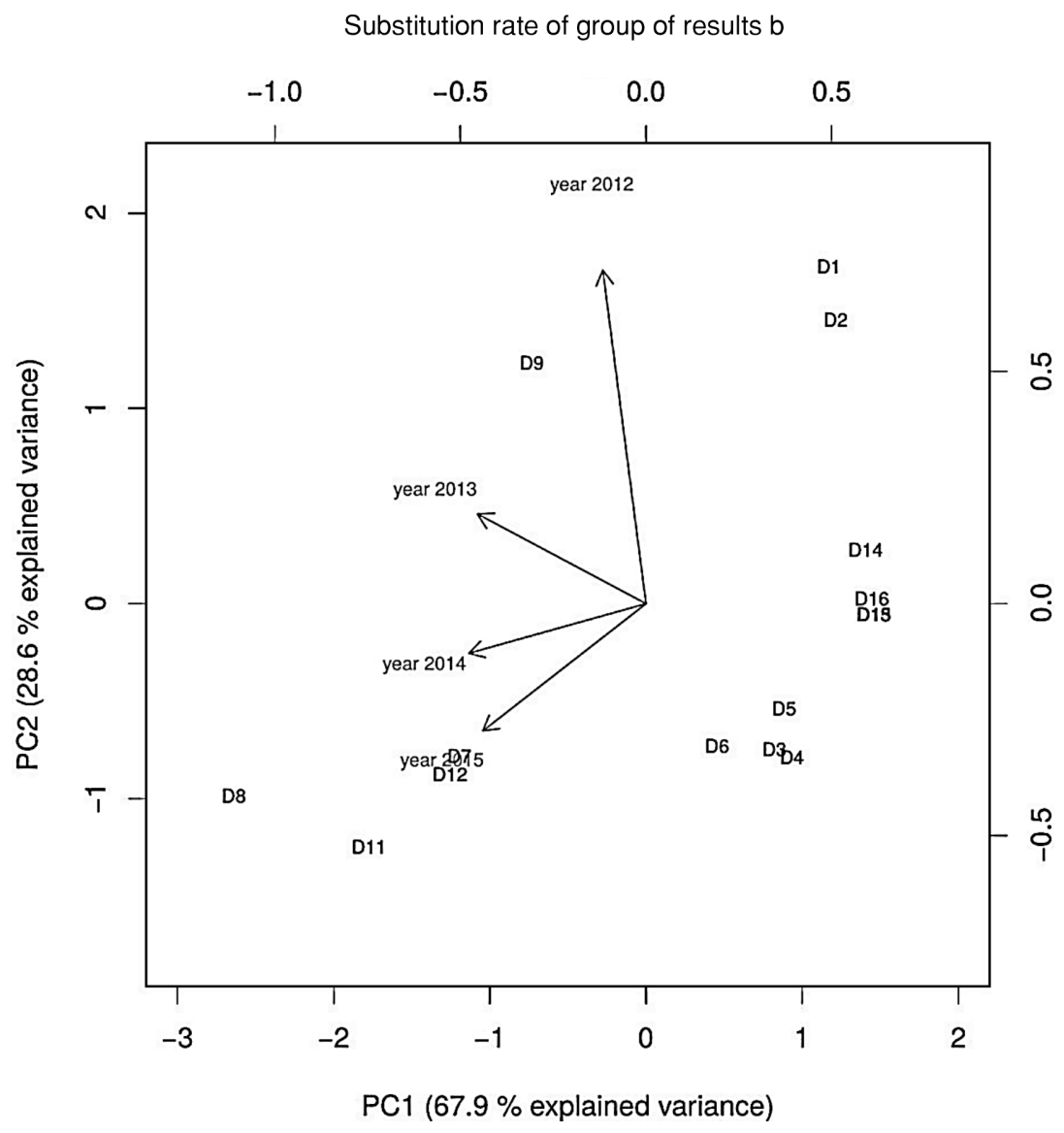

type of pen and c) the identified errors. Taking into consideration safety concerns regarding substitution, the question arises about whether the medical doctors are aware of their patients' drug substitution, and when to educate patients in the use of different injectors if the substitution is dependent on the type of pen, and whether the knowledge of an individual patient at the pharmacy is sufficient to enable such substitution without the participation of a medical doctor. Access to univocal, electronic information of prescribed and dispensed drugs for the medical profession both at the prescribing and dispensing level is more than essential for the safety of the patient, the medical professionals and for a hermetic system. Additionally, principal component analysis (PCA) was performed to illustrate the results from Tables 3 and 4 (Figs. 3 and 4). In Figures 3 and 4 the vectors, which represent primary variables, are the subsequent years 2012, 2013, 2014, 2015 and the symbols C and D represent individual cases of substitution. In the case of Figure 3,
PC1 reflects $85.9 \%$ explained variance and $\mathrm{PC} 2$ 9.68\%, and in Figure 4, PC1 67.9\% and PC2 28.6\%, respectively. In Figure 3 it is possible to observe similarities among cases grouped in a cluster.

The ability to plan is a key factor in the deliberative choice of resources, which, often stretched over a very long period of time, are to serve the achievement of defined objectives. The theory of planning is based on rationales. This ability to plan is not narrowed down only to a unit or to individual plans. Very often, the goals which are set concern the effort, engagement, and coordination of many groups of individuals. Therefore, the recognizable attribute of human subjectivity is the ability to enact collaborative, mutual plans and thus share in their fulfillment $(29,30)$. From the health policy point of view, this results also in a role division. According to Shapiro, "laws are plans for living together and legal systems are institutions that create certain kinds of plans for societies to follow". "Plans can be used as guides to conduct by different people" - is a 
very specific claim. "Shared plans coordinate behavior more efficiently than improvisation, especially where 'complex, contentious, and arbitrary' problems are encountered" (29). The subject of drug substitution is without a doubt a complex activity of health policy planning. It demands knowledge and skill, without which the participants are likely to distrust their own judgments or the judgments of other participants.

Economics helps to understand the law in a different way, which is extremely useful for health policy planning. Through economics, the law is seen as a stimulus for a change of behavior. In terms of drug substitution itself, the influence of legal resolutions on the outcome of the activity of the individual is noticeable. The system must here be a stimulus for the cautious in order not to cause detriment (31) to patients and medical professionals. The detriment is seen as the result of inappropriate, lacking, misleading or neglected regulations.

\section{Conflict of interest}

No conflict of interest is declared.

\section{REFERENCES}

1. WHO. Biologicals. Available from: http:// www.who.int/biologicals/biotherapeutics/biotherapeutic-products/en/. (Accessed April 3, 2017).

2. WHO. Biologicals. Available from: http:// www.who.int/biologicals/biotherapeutics/similar biotherapeutic products/en/. (Accessed April 3, 2017).

3. EMA. Biosimilar medicines. Available from: http://www.ema.europa.eu/docs/en GB/document library/Medicine QA/2009/12/WC5000 20062.pdf. (Accessed April 3, 2017).

4. Danese S., Bonovas S., Peyrin-Biroulet L.: Gastroentero. Hepat. 14, 22 (2017).

5. FDA. What Are "Biologics". Available from: http://www.fda.gov/AboutFDA/CentersOffices /OfficeofMedicalProductsandTobacco/CBER/u cm133077.htm. (Accessed April 3, 2017).

6. WHO. Biologicals. Available from: http:// www.who.int/biologicals/areas/biological therapeutics/BIOTHERAPEUTICS Ghana WS report HK 18 Feb 2016.pdf?ua=1. (Accessed April 3, 2017).

7. Hospital Pharmacy Europe. At the dawn of biosimilar insulins. Available from: http:// www.hospitalpharmacyeurope.com/diabetes/da wn-biosimilar-insulins. (Accessed April 3, 2017).
8. Chow S., Endrenyi L., Lachenbruch P.A., Yang L., Chi E.: Biosimilars. 1, 13 (2011).

9. Gruchała K.A., Zimmermann A.: Acta Pol. Pharm. 74, 1599 (2017).

10. Mathers C.D., Loncar D.: PLoS Med. 11, e442 (2006).

11. WHO. Diabetes. Available from: http://www. who.int/diabetes/global-report/WHD2016 Diabetes Infographic v2.pdf?ua=1. (Accessed April 3, 2017).

12. WHO. Biological Qualifier An INN Proposal. Available from: http://www.who.int/medicines/ services/inn/WHO INN BQ proposal 2015.pdf? ua=1. (Accessed April 3, 2017).

13. Fernandez-Lopez S., Kazzaz D., Bashir M., McLaughilin T.: J. Manag. Care Spec. Ph. 21, 188 (2015).

14. Mühlhauser I., Berger M.: J. Intern. Med. 4, 321 (1993).

15. Kitabchi A.E., Gosmanov A.R.: Am. J. of Med. Sci. 2, 136 (2012).

16. Krämer I., Blüher M., Kuhlmann M.K., Heinemann L.: Dtsch. Med. Wochenschr. 21, 1565 (2016).

17. Andersson P.O., Wikby A., Stenström U., Hörnquist J.O.: Diabetes Res. Clin. Pract. 36, 169 (1997).

18. Chantelau E., Schiffers T., Schütze J., Hansen B.: Patient Educ. Couns. 2, 167 (1997).

19. Graff M.R., McClanahan M.A.: Clin. Ther. 3, 486 (1998).

20. Pillai O., Panchagnula R.: Drug Discov. Today. 20, 1056 (2001).

21. Urakami T., Kuwabara R., Aoki M., Okuno M., Suzuki J.: Endocrine J. 2, 159 (2016).

22. Vora J., Cariou B., Evans M., Gross J.L. et al.: Diabetes Res. Clin. Pract. 1, 19 (2015).

23. Reaney M., Cypryk K., Tentolouris N. et al.: Diabetes Res. Clin. Pract. 2, 231 (2012).

24. Olech E.: Semin. Arthrisis Rheum. 45, 1 (2016).

25. PharmaTimes. Available from: http://www. pharmatimes.com/news/france moving ahead with biosimilar substitution 1001811. (Accessed April 3, 2017).

26. Medicines Evaluation Boaard. Clarification of stance on biological and biosimilar medicines. Available from: https://english.cbg-meb.nl/latest/news/2015/08/17/clarification-of-stance-onbiological-and-biosimilar-medicines. (Accessed April 3, 2017).

27. WHO. Essential medicines and health products. Available from: http://www.who.int/medicines/publications/druginformation/innlists/en/. (Accessed April 3, 2017). 
28. R: A Language and Environment for Statistical Computing. R Core Team, R Foundation for Statistical Computing. Available from: https:// www.r-project.org/. (Accessed April 3, 2017).

29. Harvard University Press 2010. Shapiro's Planning Theory of Law (a review of Scott Schapiro, Legality). Available from: https:// mcbridesguides.files.wordpress.com/2014/08/s hapiros-planning-theory-of-law.pdf. (Accessed April 3, 2017).

30. Brożek B.: Normatywność Prawa. Warszawa Wolters Kluwer SA (2012).

31. Cooter R., Ulen T.: Law and economics. Harlow Berkeley Law Books (2011).

Received: 24.06. 2017 